\title{
Esophageal perforation: diagnosis, management and decision-making - a retrospective tertiary centre study
}

\author{
Nader El-Sourani[D \\ Clinic of General and Visceral Surgery, Oldenburg University Hospital, Oldenburg, Germany
}

\begin{abstract}
Objective: Perforation of the esophagus is an extremely rare but life-threatening emergency associated with a high morbidity and mortality. Therefore, time-management is of utmost importance and it is crucial to have an algorithm for diagnostic methods and the subsequent decision-making process.

Material and Methods: All patients who were diagnosed with an esophageal perforation between 2010 and 2020 at our university hospital were retrospectively analysed. In addition to patient demographics, the diagnostic method, treatment strategy, defect size and location, etiology and mortality were recorded.

Results: A total of 27 patients were identified with an esophageal perforation. All patients were diagnosed through a computed tomography initiating the treatment algorithm 18 patients underwent conservative/endoscopic treatment, while 9 patients received primary surgery for event-related complications. The overall mortality rate was $25.9 \%, 11.1 \%$ within the endoscopic group and $55 \%$ within the surgical group.
\end{abstract}

Conclusion: A timely diagnosis in cases of an esophageal perforation is of utmost importance. Therefore, every patient should undergo an emergency computed tomography (CT) with oral and intravenous contrast followed by an upper endoscopy if event-related complications are ruled out in the CT.

Keywords: Esophagus, perforation, Boerhaave, endoscopy

Cite this article as: El-Sourani N. Esophageal perforation: diagnosis, management and decision-making - a retrospective tertiary centre study. Turk J Surg 2021; 37 (4): 342346.

\section{Corresponding Author}

Nader El-Sourani

E-mail: nader@elsourani.com

Received: 22.03 .2021

Accepted: 12.08 .202

Available Online Date: 31.12 .2021

(o Copyright 2021 by Turkish Surgical Society Available online at www.turkjsurg.com

DOI: $10.47717 /$ turkjsurg.2021.5289

\section{INTRODUCTION}

Perforation of the esophagus is an extremely rare but life-threatening emergency associated with a high morbidity and mortality. The incidence is extremely low with a reported age-standard incidence of 3.1/1000000 a year (1). The time-management is of utmost importance regarding this patient collective, as the reported mortality increases dramatically with time passed after diagnosis. Across several studies, the mortality ranges between $10 \%$ to $25 \%$ within the first $24 \mathrm{~h}$ after perforation and increases to $40 \%$ to $60 \%$ if the treatment is delayed beyond this point. One of the main reasons of this vastly increasing mortality with time seems to be the anatomical configuration and location of the esophagus (2). Due to the absence of immunocompetent tissue, bacteria and digestive enzymes have an easy entry to the mediastinum leading to the development of complications such as sepsis, empyema, mediastinitis and organ failures. To combat that problem, several studies tried to create a treatment algorithm, however, up to this date is is no clear consensus (3).

Perforation of the esophagus can be due to different etiologies. The most common cause by far is iatrogenic. latrogenic causes amount up to $70 \%$ of esophageal perforations (4). Endoscopic procedures are the most common cause of iatrogenic causes with a reported risk of $0.03 \%$. This, however, increases by a manifold if therapeutic procedures are carried out during the time of endoscopy. The risk of perforation for endoscopic laser therapy and esophageal stent placement is $4.6 \%$ and $5-25 \%$ respectively (4). Other causes include trauma to the chest and upper abdomen, blunt injuries, spontaneous perforation of the esophagus first described by the Dutch physician Hermann Boerhaave in 1724 (5) and foreign bodies.

Due to its anatomical structure, perforation of the esophagus has a higher chance of occurring at four predisposing positions: 1) the Killian-Triangle; a muscle free 
zone in the proximal third of the esophagus, 2) the crossing at the aortic arch, 3) the connection to the left main bronchus and 4) the esophagogastric junction.

Diagnosis and management of esophageal perforations are crucial. However, diagnostic errors are prevalent due to the presenting symptom of acute chest pain leading often to misdiagnosis such as a perforated ulcer, followed by myocardial infarction, pulmonary embolism, dissection aneurysm and pancreatitis. A triad of vomiting, chest pain and emphysema known as the Mackler triad should be used while taking the initial history. The extent of the defect, the localisation of the defect and the time passed between the event and begin of therapy should all be used in the decision making process (2).

The aim of this study is to help to determine the most appropriate diagnostic and therapeutic approach for surgical and non-surgical centres confronted with the possible diagnosis of an esophageal perforation

\section{MATERIAL and METHODS}

All patients who were diagnosed with an esophageal perforation between 2010 and 2020 were included in this study. The dataset was retrospectively analysed. In addition to patient demographics following parameters were analysed: diagnostic method of choice, etiology, location and size of the defect, treatment strategy and mortality.

\section{Statistical Analysis}

The statistical analysis was performed with IBM SPSS Statistics Version 24 64-Bit-Version for Mac OS. Continuous variables were exposed as medians. Categorical variables were compared using Fisher's exact test or chi-square test.

\section{Ethical Considerations}

The study was evaluated by the local ethics committee and no objection was mentioned. The approval was waived because of the retrospective study design.

\section{RESULTS}

A total of 27 patients were identified that were diagnosed with and treated for an esophageal perforation. The median age was 70 (range: 29-86 years). The median ASA classification was 3 (range: $2-4$ ). Out of 27 patients, $n=15$ were male (55.6\%) and $n=12$ were female (44.4\%). The etiology consisted of three main events: latrogenic causes, Boerhaave Syndrome and foreign body ingestion with a distribution of $44.4 \%, 44.4 \%$ and $11.1 \%$ respectively. The most common iatrogenic cause was endoscopy in combination with a treatment (66\%). 17 patients were diagnosed and treated within 24h, while 9 patients were diagnosed and treated after $24 \mathrm{~h}$. All 9 patients who had a delayed treatment response were referred to us from different hospitals. Out of 27 patients, $n=17$ had a defect size of $1-3 \mathrm{~cm}$ and $n=10$ patients $a$ defect size of $>3 \mathrm{~cm}$. All patients were diagnosed with an initial computed tomography (CT) followed by an upper endoscopy (UE) to asses the size of the defect, the localisation and to asses if a conservative or surgical treatment is necessary. $n=18$ patients were treated conservatively, in $n=9$ cases surgery was performed. Patient demographics can be seen in Table 1.

\section{Conservative Treatment}

A total of 18/27 patients were treated conservatively through endoscopic stent placement, clipping of the defect or endoscopic vacuum-therapy. $n=13$ of those conservative treated patients were treated within 24 hours, $n=5$ were treated after $24 \mathrm{~h}$. The defect was located in $n=13$ patients in the distal third, in $n=2$ in the middle third and in $n=3$ in the proximal third of the esophagus. 13 patients had a defect of $1-3 \mathrm{~cm}$ and 5 patients had a defect $>3$ $\mathrm{cm}$. All out of two patients survived, the mortality rate within the conservative group is $11.1 \%$.

\section{Surgical Treatment}

A total of $9 / 27$ patients were treated surgically. $n=4$ were treated within 24 hours and $n=5$ were treated after $24 \mathrm{~h}$. The defect was located in $n=7$ patients in the distal thirds, in $n=1$ in the middle third and in $n=1$ in the proximal third of the esophagus. 4 patients had a defect size of $1-3 \mathrm{~cm}$ while 5 patients had a defect size of $>3 \mathrm{~cm}$. 5 out of 9 patients died postoperatively, with a respectively mortality rate of $55 \%$ within the surgical treatment group.

\section{Mortality}

A total of 27 patients underwent treatment for an esophageal perforation. The overall mortality rate is $7 / 27,25.9 \%$ respectively. The mortality rate within the conservative treatment group is lower compared to the mortality group within the surgical treatment group. Out of those 7 patients, 5 had a defect size $>3 \mathrm{~cm}$ while only 2 had a defect size $<3 \mathrm{~cm}$. A total of $\mathrm{n}=6$ patients who did not survive were treated after 24 hours. Statistical analysis revealed that there is a statistical significance between surgical treatment and mortality $(p=0.023)$.

\section{DISCUSSION}

As mentioned above, perforation of the esophagus happens on an extremely rare occasion and is therefore not easily diagnosed and often misdiagnosed. Thus, a timely diagnosis and appropriate management is of utmost importance but remains challenging to this date. In case of a diagnosis it is crucial to refer patients to large teaching or university hospitals as a multidisciplinary team is at hand and a fast consensus on further treatment can be achieved (6). As the esophagus is not covered by immunocompetent tissue such as other structures in the abdomen, the infectious and inflammatory response after a perforation can disseminate very quickly leading to complications such as mediastinitis, sepsis, empyema and even organ failure and death. In the case of an advanced local inflamma- 
Table 1. Shows the retrospectively evaluated data of patients in this cohort study

\begin{tabular}{|c|c|c|c|c|c|c|c|c|}
\hline Patient & Etiology & Diagnostic & Localization & Defect & Time to Management & Treatment & Referral & Mortality \\
\hline 1 & ERCP & $C T+U E$ & Distal third & $4 \mathrm{~cm}$ & $<24 h$ & Surgical & Y & Y \\
\hline 2 & Incarcerated Hernia & $C T+U E$ & Distal third & $1 \mathrm{~cm}$ & $<24 h$ & Surgical & $\mathrm{N}$ & Y \\
\hline 3 & Boerhaave & $\mathrm{CT}+\mathrm{UE}$ & Distal third & $4 \mathrm{~cm}$ & $<24 h$ & Surgical & Y & $\mathrm{N}$ \\
\hline 4 & Boerhaave & $\mathrm{CT}+\mathrm{UE}$ & Distal third & $5 \mathrm{~cm}$ & $<24 h$ & Surgical & Y & $\mathrm{N}$ \\
\hline 5 & Baloondilatation & $\mathrm{CT}+\mathrm{UE}$ & Distal third & $2 \mathrm{~cm}$ & $<24 h$ & Endoscopic & Y & $\mathrm{N}$ \\
\hline 6 & ESR & $\mathrm{CT}+\mathrm{UE}$ & Distal third & $1 \mathrm{~cm}$ & $<24 h$ & Endoscopic & $\mathrm{N}$ & $\mathrm{N}$ \\
\hline 7 & Boerhaave & $\mathrm{CT}+\mathrm{UE}$ & Distal third & $1 \mathrm{~cm}$ & $<24 h$ & Endoscopic & N & N \\
\hline 8 & Boerhaave & $\mathrm{CT}+\mathrm{UE}$ & Distal third & $1.2 \mathrm{~cm}$ & $<24 \mathrm{~h}$ & Surgical & N & $\mathrm{N}$ \\
\hline 9 & Boerhaave & $\mathrm{CT}+\mathrm{UE}$ & Distal third & $1 \mathrm{~cm}$ & $<24 h$ & Endoscopic & $\mathrm{N}$ & $\mathrm{N}$ \\
\hline 10 & Panendoscopy & $C T+U E$ & Distal third & $1.5 \mathrm{~cm}$ & $<24 h$ & Endoscopic & N & $\mathrm{N}$ \\
\hline 11 & Boerhaave & $\mathrm{CT}+\mathrm{UE}$ & Distal third & $2.5 \mathrm{~cm}$ & $<24 h$ & Endoscopic & $N$ & $\mathrm{~N}$ \\
\hline 12 & Boerhaave & $\mathrm{CT}+\mathrm{UE}$ & Middle third & $3 \mathrm{~cm}$ & $<24 h$ & Endoscopic & $\mathrm{N}$ & $\mathrm{N}$ \\
\hline 13 & Boerhaave & $\mathrm{CT}+\mathrm{UE}$ & Distal third & $1 \mathrm{~cm}$ & $<24 h$ & Endoscopic & $\mathrm{N}$ & $\mathrm{N}$ \\
\hline 14 & TEE & $\mathrm{CT}+\mathrm{UE}$ & Distal third & $2 \mathrm{~cm}$ & $<24 h$ & Endoscopic & $\mathrm{N}$ & $\mathrm{N}$ \\
\hline 15 & Boerhaave & $\mathrm{CT}+\mathrm{UE}$ & Proximal third & $1 \mathrm{~cm}$ & $>24 h$ & Endoscopic & Y & $\mathrm{N}$ \\
\hline 16 & Boerhaave & $\mathrm{CT}+\mathrm{UE}$ & Distal third & $4 \mathrm{~cm}$ & $>24 \mathrm{~h}$ & Endoscopic & Y & $\mathrm{N}$ \\
\hline 17 & TEE & $C T+U E$ & Distal third & $8 \mathrm{~cm}$ & $>24 h$ & Endoscopic & Y & Y \\
\hline 18 & Baloondilatation & $\mathrm{CT}+\mathrm{UE}$ & Proximal third & $5 \mathrm{~cm}$ & $>24 h$ & Endoscopic & Y & N \\
\hline 19 & Boerhaave & $C T+U E$ & Proximal third & $1 \mathrm{~cm}$ & $>24 h$ & Conservative & Y & $\mathrm{N}$ \\
\hline 20 & EMR & $\mathrm{CT}+\mathrm{UE}$ & Distal third & $3 \mathrm{~cm}$ & $>24 h$ & Endoscopic & Y & Y \\
\hline 21 & Foreign Body & $C T+U E$ & Middle third & $0.6 \mathrm{~cm}$ & $<24 h$ & Endoscopic & $\mathrm{N}$ & $\mathrm{N}$ \\
\hline 22 & Dilatation & $\mathrm{CT}+\mathrm{UE}$ & Middle third & $0.3 \mathrm{~cm}$ & $>24 h$ & Surgical & Y & $\mathrm{N}$ \\
\hline 23 & Fundoplicatio & $C T+U E$ & Distal third & $1 \mathrm{~cm}$ & $<24 h$ & Endoscopic & $\mathrm{N}$ & $\mathrm{N}$ \\
\hline 24 & Foreign Body & $\mathrm{CT}+\mathrm{UE}$ & Distal third & $1 \mathrm{~cm}$ & $>24 h$ & Surgical & $\mathrm{N}$ & Y \\
\hline 25 & Foreing Body & $C T+U E$ & Distal third & $5 \mathrm{~cm}$ & $>24 h$ & Conservative & Y & $\mathrm{N}$ \\
\hline 26 & Feeding-Tube & $\mathrm{CT}+\mathrm{UE}$ & Distal third & $5 \mathrm{~cm}$ & $<24 h$ & Surgical & Y & \\
\hline 27 & Boerhaave & $C T+U E$ & Proximal third & $2 \mathrm{~cm}$ & $>24 h$ & Surgical & Y & Y \\
\hline
\end{tabular}

tion, one must consider primary surgery with the placement of multiple drains to warrant a successful outcome (7). In the case of "fresh" perforations without any signs of event-related complications or sepsis a conservative or endoscopic treatment should be preferred (8). The results of our retrospective and descriptive analysis matches those of the already available literature on the management and treatment of esophageal perforations. Our data suggests, that patients with a large defect and where treatment was initiated 24 hours after the initial event have a poorer outcome compared to those with a small defect and when treatment was initiated within 24 hours. In addition, patients who needed to undergo surgery due to event-related complications had a poorer outcome as well, as those patients were in most cases septic. This was also shown by Ryom P et al. 2011 and Bhatia P et al. 2011 (9). Proven predictors for a nega- tive outcome are malignant associated perforations and an existing mediastinitis at the point of diagnosis $(10,11)$. Boerhaavee syndrome compared to iatrogenic perforations or perforations caused by foreign bodies is very difficult to diagnose and often primarily misdiagnosed leading to a time delay before treatment is initiated thus leading to an increased mortality when compared to iatrogenic perforations (12) as those perforations are identified most often during the intervention and can be timely managed so that event associated complications do not arise. This is also in concordance with our date, as most patients who died suffered from Boerhaave syndrome.

The available literature suggests, that all patients with an esophageal perforation should undergo a computed tomography (Figure 1 and 2) followed by an upper endoscopy (Figure 3). If 


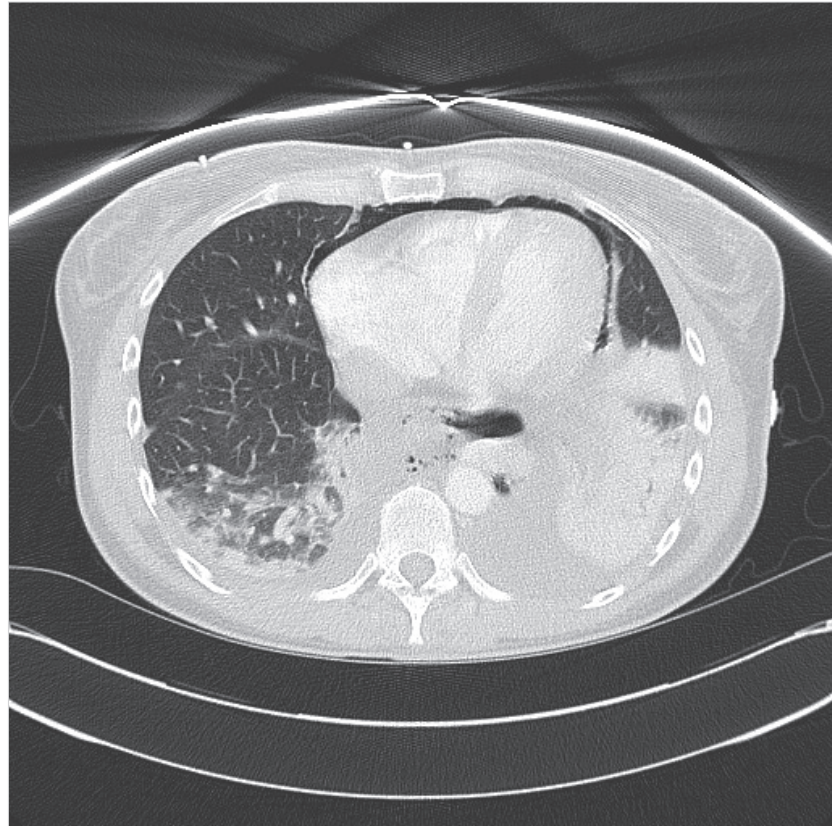

Figure 1. CT showing free air in the mediastinum lateral to the esophagus.

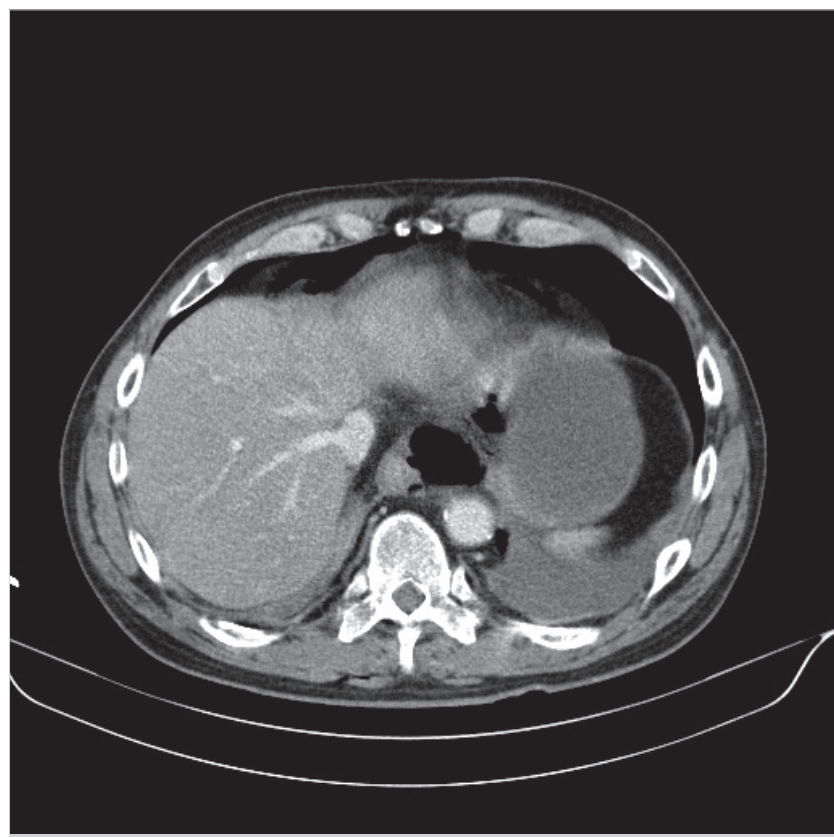

Figure 2. CT showing massive free air in the mediastinum lateral to the esophagus with subsequent mediastinitis.

a CT shows an esophageal perforation without any complications such as mediastinitis or empyema, a conservative or endoscopic treatment can be successful. In case of large defects in combination with complications and sepsis a surgery is necessary. Therefore, a computed tomography with contrast is the best option as it is able to illustrate the perforation as well as a surrounding inflammatory process (De Lutio di Castelguidone E et al, Radiol Med 2005).
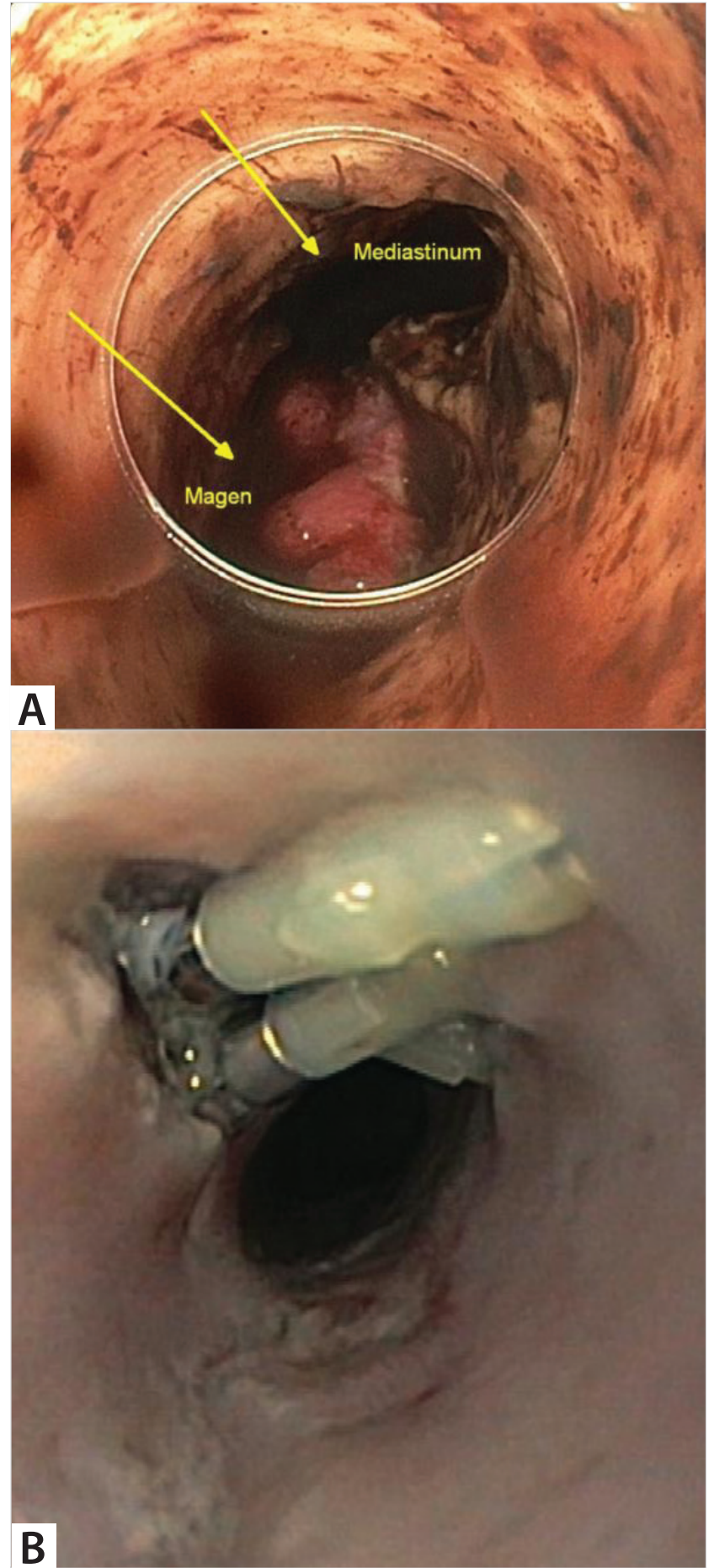

Figure 3. A. Endoscopy with bottom arrow showing the stomach and upper arrow showing the mediastinum. B. showing the defect after endoscopic clipping.

To conclude our findings, the most important factor is a timely diagnosis which can be warranted by a CT with oral and intravenous contrast medium followed by an interventional upper endoscopy and or primary surgery depending on the presence of complications, signs of sepsis and clinical status of the patient. 


\section{CONCLUSION}

Esophageal perforation is an extremely rare but life-threatening condition. The outcome depends on a timely diagnosis and a fast and multidisciplinary management of the patient. A treatment algorithm should be available in every larger centre tackling that rare condition to achieve the best possible outcome for their patients.

Ethics Committee Approval: This study approval was obtained from Oldenburg University Hospital (Decision No: ACH-E.N, Date: 22.04.2021).

Peer-review: Externally peer-reviewed.

Author Contributions: Concept - N.E.S.; Design - N.E.S.; Supervision - N.E.S.; Materials - N.E.S.; Data Collection and/or Processing - N.E.S.; Analysis and/or Interpretation - N.E.S.; Literature Search - N.E.S.; Writing Manuscript - N.E.S. Critical Reviews - N.E.S.

Conflict of Interest: The authors have no conflicts of interest to declare.

Financial Disclosure: The authors declared that this study has received no financial support.

\section{REFERENCES}

1. Vidarsdottir H, Blondal S, Alfredsson H, Geirsson A, Gudbjartsson T. Oesophageal perforations in Iceland: A whole population study on incidence, aetiology and surgical outcome. Thorac Cardiovasc Surg 2010; 58(8): 476-80. [CrossRef]

2. Troja A, Käse P, El-Sourani N, Miftode S, Raab HR, Antolovic D. Treatment of esophageal perforation: A single-center expertise. Scand J Surg 2015; 104(3): 191-5. [CrossRef]
3. de Schipper JP, Pull ter Gunne AF, Oostvogel HJ, van Laarhoven CJ. Spontaneous rupture of the oesophagus: Boerhaave's syndrome in 2008. Literature review and treatment algorithm. Dig Surg 2009; 26(1): 1-6. [CrossRef]

4. Kaman L, labal J, Kundil B, Kochhar R. Management of esophageal perforation in adults. Gastroenterology Res 2010; 3(6): 235-44. [CrossRef]

5. Boerhaave H. Atrocis, nec descripti prius, morbi historia secundum medicae artis leges conscripta, lugduni batavorum, boutesteniana. Bull Med Libr Assoc 1955; 43(2): 217-40. [CrossRef]

6. Ryom P, Ravn JB, Penninga L, Schmidt S, Iversen MG, Skov-Olsen P, et al. Aetiology, treatment and mortality after oesophageal perforation in Denmark. Dan Med Bull 2011; 58(5): A4267. [CrossRef]

7. Schmidt SC, Strauch S, Rösch T, Veltzke-Schlieker W, Jonas S, Pratschke J, et al. Management of esophageal perforations. Surg Endosc 2010; 24(11): 2809-13. [CrossRef]

8. Chirica M, Champault A, Dray X, Sulpice L, Munoz-Bongrand N, Sarfati E, et al. Esophageal perforations. J Visc Surg 2010; 147(3): e1 17-28. [CrossRef]

9. Bhatia P, Fortin D, Inculet RI, Malthaner RA. Current concepts in the management of esophageal perforations: A twenty-seven year Canadian experience. Ann Thorac Surg 2011; 92(1): 209-15. [CrossRef]

10. Amir Al, Van Dullemen H, Plukker, JT. Selective approach in the treatment of esophageal perforations. Scand J Gastroenterol 2004; 39: 418-22. [CrossRef]

11. Gupta, NM, Kaman, L. Personal management of 57 consecutive patients with esophageal perforation. Am J Surg 2004; 187: 58-63. [CrossRef]

12. Vial CM, Whyte RI. Boerhaave's syndrome: Diagnosis and treatment. Surg Clin North Am 2005; 85: 515-24. [CrossRef]

\section{ORIJINAL ÇALIŞMA-ÖZET}

Turk J Surg 2021; 37 (4): 342-346

\section{Özofagus perforasyonu: Teşhis, yönetim ve karar verme - üçüncü basamak bir merkezde retrospektif kohort bir çalışma}

Nader El-Sourani

Oldenburg Üniversite Hastanesi, Genel Cerrahi ve Karın Cerrahisi Kliniği, Oldenburg, Almanya

\section{ÖZET}

Giriş ve Amaç: Özofagus perforasyonu, yüksek morbidite ve mortalite ile ilişkili son derece nadir ancak bir o kadar hayati tehlike oluşturan acil bir durumdur. Bu sebeple, zaman yönetimi son derece önemli olmakla birlikte tanısal yöntemler açısından ve bunları takip eden karar verme aşamasında bir algoritmaya sahip olmak önemlidir.

Gereç ve Yöntem: Hastanemizde 2010 ve 2020 yılları arasında özofagus perforasyonu tanısı alan tüm hastalar retrospektif olarak incelendi. Hasta demografik bilgilerine ek olarak tanısal yöntem, tedavi stratejisi, defekt boyutu ve lokasyonu ile etiyoloji ve mortalite bulguları kaydedildi.

Bulgular: Özofagus perforasyonu olan toplam 27 hasta belirlendi. Tüm hastalar tedavi algoritmasını başlatan bilgisayarlı tomografi ile tanı alırken 18 hasta konvansiyonel/endoskopik yöntemle, dokuz hasta durum ile ilişkili komplikasyonlar sebebiyle primer cerrahi ile tedavi edildi. Toplam mortalite oranı $\% 25,9$ olup bu oranın $\% 11,1^{\prime} i$ endoskopik grupta $\% 55^{\prime} i$ ise cerrahi müdahale grubundaydı.

Sonuç: Özofagus perforasyonu olan olgularda zamanında tanı hayati öneme sahiptir. Dolayısıyla, her hasta oral ve intravenöz kontrast materyali ile acil bilgisayarlı tomografiye (BT) alınmalı ve BT'de durum ile ilişkili komplikasyonlar elendiği takdirde hastalara üst endoskopi uygulanmalıdır.

Anahtar Kelimeler: Özofagus, perforasyon, Boerhaave, endoskopi

Doi: $10.47717 /$ turkjsurg.2021.5289 